MAREK SMOLAK

\title{
NATURALIZM METODOLOGICZNY W NAUKACH PRAWNYCH UWAGI NA MARGINESIE KSIĄŻKI WOJCIECHA PATRYASA PRÓBA WYJAŚNIENIA DOMNIEMAŃ PRAWNYCH
}

I. Zadanie, przed jakim stanąłem, to jest prezentacji książki Wojciecha Patryasa Próba wyjaśnienia domniemań prawnych ${ }^{1}$, wymaga ode mnie na wstępie dokonania trudnego wyboru. Realizując owo zadanie, można bowiem przyjąć dwa stanowiska. W ramach pierwszego z nich przedstawia się całość zagadnień podejmowanych w książce przez danego Autora, w ramach drugiego - dokonuje się wyboru określonej wiodącej myśli Autora, wskazując jej przewagi lub słabości. Zarówno pierwsze, jak i drugie ze wspomnianych stanowisk ma swoje wady. Przyjąwszy pierwsze z nich, recenzent może narazić się na zarzut pobieżności w prezentowaniu tez i idei zawartych w recenzowanej książce. Przyjąwszy drugie, może z kolei narazić się na zarzut arbitralności w wyborze prezentowanych poglądów. Zdając sobie sprawę $\mathrm{z}$ powyższych zagrożeń, przyjąłem drugie z wymienionych stanowisk. Nie zamierzam zatem prezentować wszystkich zagadnień, jakie poruszał w swej książce W. Patryas, tym bardziej że recenzowana książka mimo swej niewielkiej objętości porusza wiele fundamentalnych zagadnień podejmowanych przez teoretyków prawa. Skoncentruję więc swoją uwagę na tych jego koncepcjach, które wnoszą element nowości do teorii prawa, by następnie sformułować uwagi o charakterze ogólniejszym.

Rozpocznę moje rozważania nad książką W. Patryasa od wskazania ogólnego tła jego dociekań. Otóż punktem wyjścia rozważań Autora jest spór co do metodologicznego charakteru prawoznawstwa. Nakreślmy w najogólniejszym zarysie, na czym ów spór polega. Powszechnie przyjmuje się, że ogół dziedzin naukowych dzieli się na nauki formalne oraz nauki empiryczne. Do nauk formalnych standardowo zalicza się logikę oraz matematykę. Natomiast wszystkie pozostałe nauki to nauki empiryczne. Bezsporne jest to, że nauki prawne nie sa naukami formalnymi. Natomiast co do ich empirycznego charakteru nie ma już takiej zgody wśród teoretyków prawa. Jedni z nich uważają nauki prawne za nauki empiryczne (tak np. utrzymują Z. Ziembiński czy L. Nowak). Inni z kolei odmawiaja im tego statusu (tak np. argumentuje Z. Pulka). Bezsporne jest również to, że nauki prawne w ramach nauk

${ }^{1}$ W. Patryas, Próba wyjaśnienia domniemań prawnych, Poznań 2011. 
empirycznych wchodzą w skład nauk społecznych (ewentualnie humanistycznych), a co za tym idzie - nie są naukami przyrodniczymi (naturalnymi). Jeżeli dodamy do tych podziałów podział nauk na nauki praktyczne i teoretyczne, to obraz statusu metodologicznego nauk prawnych wygląda co najmniej zawile.

Ów spór, jak wiadomo, zaowocował dwoma stanowiskami. Wedle pierwszego $\mathrm{z}$ nich - określanego mianem naturalizmu metodologicznego - nauki prawne i przyrodnicze powinny być ujmowane podobnie ${ }^{2}$. $\mathrm{Z}$ tych powodów zadania oraz cele, jakie się stawia obu naukom, powinny być takie same. Skoro zaś podstawowym zadaniem nauk przyrodniczych jest wyjaśnianie zjawisk naturalnych, to podstawowym zadaniem nauk prawnych jest również wyjaśnianie, tyle że zjawisk prawnych. Natomiast w stanowisku określanym mianem antynaturalizmu metodologicznego zadania i cele nauk prawnych sa potraktowane odmienne aniżeli w naukach przyrodniczych. Otóż fundamentalnym zadaniem nauk prawnych jest rozumienie zjawisk prawnych (czynności czy też wytworów kulturowych), a nie ich wyjaśnienie ${ }^{3}$. Jak podkreśla W. Patryas, stanowiska powyższe sa nie do pogodzenia. Jedynie zatem, co pozostaje badaczowi, to prowadzenie długotrwałej praktyki badawczej, dzięki niej bowiem można wykazać, które ze stanowisk przynosi lepsze koncepcje naukowe (s. 11).

Recenzowaną książkę traktować należy, zgodnie z deklaracjami Autora, jako element praktyki badawczej, której zadaniem jest wykazanie, że stanowisko naturalistyczne w metodologii nauk prawnych przynosi znacznie lepsze rezultaty aniżeli stanowisko opozycyjne. W tym obszarze zagadnień Autor stawia sobie zadanie szczególne, a mianowicie wyjaśnienie faktu występowania w niektórych aktach normatywnych domniemań prawnych.

W. Patryas, zdając sobie sprawę z problemów metodologicznych, jakie w naukach prawnych nastręcza wyjaśnienie faktu występowania domniemań prawnych w aktach normatywnych w oparciu o model Hempla (wyjaśnianie nomologiczno-dedukcyjne), wskazał na szczególną osobliwość teorii prawa. Otóż niezależnie od kultury prawnej czy tradycji, a nawet systemów prawnych, badacze prawa konstruują różnego rodzaju reguły. Wystarczy w tym względzie powołać przykład reguł pierwotnych i wtórnych H. L. A. Harta, reguły instytutywnej N. MacCormicka, a z polskiego podwórka dyrektyw wykładni prawa zaproponowane przez takich badaczy, jak J. Wróblewski, Z. Ziembiński czy M. Zieliński. Ta konstatacja naprowadziła W. Patryasa na myśl, by wyjaśnienie faktu występowania domniemań prawnych w aktach normatywnych przeprowadzić, wykorzystując koncepcję wyjaśniania strukturalnego. Otóż wyjaśnienie faktu występowania domniemań prawnych w aktach normatywnych nie opiera się na jakichś prawach ściśle ogólnych, ale odwołuje się do zaproponowanej przez K. Ajdukiewicza koncepcji wyjaśniania jako rozumowania opartego na regułach analogonu dowodzenia. W myśl tej idei wyjaśnienie jest wyjaśnieniem struktury reguły w najprostszym jej przypadku. Taką reguła jest norma, a w szczególności norma prawna. Owo wyjaśnianie przeprowadza się w dwóch krokach.

${ }^{2}$ Zob. A. Kozak, Naturalistyczne ujęcie prawa, w: Wprowadzenie do nauk prawnych. Leksykon tematyczny, red. A. Bator, Warszawa 2008, s. 50-52.

${ }^{3}$ Zob. J. Stelmach, w: R. Sarkowicz, J. Stelmach, Teoria prawa, Kraków 1998, s. 29. 
Pierwszy krok, zawierający dwie fazy, polega na utworzeniu adekwatnego tworu normatywnego, przez wyinterpretowanie $\mathrm{z}$ wyjaśnianych aktów normatywnych wszystkich wysłowionych w nim norm. Następnie z owych norm tworzy się jedną sekwencję, nazywaną przez Autora tworem normatywnym. Czynność ta przebiega wedle następującej reguły:

1.

(1) Każda norma jest tworem normatywnym,

(2) jeśli A oraz B są tworami normatywnymi, to A.B jest tworem normatywnym.

Reguła ta, co nietrudno zauważyć, ma charakter indukcyjny.

Drugi krok wyjaśniania strukturalnego polega, zdaniem Autora, na przekształcaniu tworów normatywnych w wytwory normatywne na podstawie reguły, która brzmi następująco:

2.

(1) Każdy twór normatywny jest wytworem normatywnym,

(2) jeśli A jest wytworem normatywnym, którego choć jedna norma zawiera wyrażenie nadające się na zwrot definiujący, to wytworem normatywnym jest też B powstały z A przez poprzedzenie A definicją opartą na tym wyrażeniu jako zwrocie definiującym oraz zastąpienie w A każdej normy zawierającej ów zwrot jej przekładem dokonanym na podstawie dołączonej definicji,

(3) jeśli A jest wytworem normatywnym zawierającym normę zakazująca, której fragment nadaje się do wyodrębnienia w postaci przepisu zezwalającego, to wytworem normatywnym jest też B powstały z A przez zastąpienie owej normy zestawem obejmującym pozostałą $\mathrm{z}$ niej $\mathrm{w}$ wyniku usunięcia tego fragmentu normę oraz sformułowany z usuniętego fragmentu przepis zezwalający (s. 13).

Przytoczyłem ten obszerny rys wyjaśnienia strukturalnego, oddaje on bowiem fundamentalną ideę książki: ciąg wytworów normatywnych, z których pierwszy jest tworem normatywnym zbudowanym na pierwszej regule, a każdy następny wywodzi się z poprzedniego przez zastosowanie doń drugiej reguły, stanowi wyjaśnienie struktury ostatniego z nich będącego aktem normatywnym lub zestawem tychże aktów. Podobnie powyższą procedurę wyjaśnienia można zastosować do tych aktów normatywnych, które zawieraja domniemania prawne (s. 14).

Taki sposób postępowania nakazuje, aby odtworzenie szczególnego rodzaju norm stanowiło odzwierciedlenie wyników postępowania dowodowego. Każda taka norma, oprócz innych niezbędnych elementów, powinna zawierać nakaz, by określony podmiot złożył oświadczenie o fragmentach swej wiedzy odzwierciedlające wynik przeprowadzonego przezeń postępowania dowodowego. Gdy adresatowi danej normy nakazane jest złożenie oświadczenia, które dokładnie odwzorowuje rezultaty takiego postępowania, wtedy mamy do czynienia z normą nakazująca adekwatne odzwierciedlenie wyników postępowania dowodowego. Gdy zaś adresatowi normy nakazane jest złożenie oświadczenia, które niedokładnie odwzorowuje rezultaty takiego postępowania, mamy wtedy do czynienia z normą nakazująca częściowo nieadekwatne odzwierciedlenie wyników postępowania dowodowego (s. 15). 
Nawiasem mówiąc, na kanwie powyższego rozróżnienia zaproponowanego przez W. Patryasa, powstaje kłopot natury językowej. Chodzi mi tutaj o zwrot „,częściowe odzwierciedlenie”. Wydaje się, że w przypadku jakiegokolwiek odzwierciedlenia mamy do czynienia z adekwatnym odwzorowywaniem rzeczywistości (np. postaci), a sugestia, iż mamy do czynienia z jakimś częściowym odzwierciedleniem, jest myląca. Myślę, że zachodzi taka sama sytuacja, jaka ma miejsce $\mathrm{z}$ podobieństwem jakichś obiektów względem siebie. Nie sposób sobie wyobrazić częściowo adekwatnego podobieństwa.

Powróćmy do omawianego powyżej przypadku, gdy adresatowi normy nakazane jest złożenie oświadczenia, które niedokładnie odwzorowuje rezultaty postępowania dowodowego. $\mathrm{W}$ tym przypadku upraszczanie norm sprowadza się do tworzenia zestawów obejmujących nie tylko krótsze normy, lecz także stosowne domniemania prawne. Zatem wyjaśnianie występowania domniemań prawnych wśród przepisów prawnych polega na konstruowaniu tworów normatywnych zawierających normy nakazujące częściowo nieadekwatne odzwierciedlenie wyników postępowania dowodowego i przekształceniu ich w wytwory obejmujące wskazane wyżej zestawy wyrażeń.

Jako że domniemania prawne związane sa $\mathrm{z}$ normami nakazującymi częściowo nieadekwatne odzwierciedlenie wyników postępowania dowodowego, skoncentrujmy naszą uwagę na tego rodzaju normach. Wojciech Patryas na podstawie art. $172 \S 2$ k.c. i art. 340 k.c. oraz art. $13 \S 2$ k.p.c., art. 16 k.p.c., art. 234 k.p.c., art. 516 k.p.c. i art. 600 k.p.c. rekonstruuje rudymentarna normę nakazującą częściowo nieadekwatne odzwierciedlenie wyników postępowania dowodowego, która brzmi następująco:

Nakazuje się każdemu sądowi rejonowemu, rozpoznającemu sprawę stwierdzenia zasiedzenia przez określoną osobę własności położonej w jego rejonie nieruchomości, który przeprowadził postępowanie dowodowe wykazujące, że osoba ta posiadała samoistnie ową nieruchomość w dwóch oddalonych od siebie momentach i który nie przeprowadził postępowania dowodowego wykazującego, że między dwom momentami, w których osoba ta posiadała samoistnie ową nieruchomość, wystąpił taki moment, w którym nie posiadała ona samoistnie tej nieruchomości, aby wtedy w postanowieniu napisał, że on w tym momencie uważa, iż osoba ta posiadała samoistnie rzeczona nieruchomość ciągle przez co najmniej trzydzieści lat (s. 26).

Norma ta, co oczywiste, stanowi podstawę do rekonstruowania domniemania prawnego, jakim jest domniemanie dobrej wiary posiadacza samoistnego. Warto zauważyć, że dyspozycja owej normy wyznacza obowiązek adresata wykonania całkowicie zależnej od jego woli czynności, jaką ma być określona wypowiedź. W wypowiedzi takiej sąd winien oświadczyć, że w danej chwili uważa, iż wskazana osoba posiadała samoistnie określoną nieruchomość ciagle przez co najmniej trzydzieści lat. Przeprowadzone jednak postępowanie dowodowe nie gwarantuje mu posiadanie takiej wiedzy. Oczywiście może się zdarzyć, że pod wpływem dowodów wykazujących posiadanie samoistne przez wskazaną osobę określonej nieruchomości na początku i na końcu tego okresu u członków składu orzekającego powstanie przedstawienie posiadania samoistnego przez owa osobę rzeczonej nieruchomości w całym tym okresie, połączone $\mathrm{z}$ silnym przeświadczeniem, że tak właśne jest, ale będzie to 
przypadek nieznajdujący wsparcia $\mathrm{w}$ rezultatach postępowania dowodowego. Jednak powyższa norma nakazuje swemu adresatowi zadeklarowanie w postanowieniu posiadania takiej wiedzy, co można dosadnie nazwać zmuszaniem sądu do kłamstwa albo określić łagodniej jako posłużenie się przez prawodawcę fikcją dotyczącą wiedzy sądu (s. 68). Sąd winien oświadczyć, że wskazana osoba posiadała samoistnie określoną nieruchomość ciągle przez co najmniej trzydzieści lat. Zdanie to opisuje pewien fakt, ale ten fakt nie podlega udowodnieniu. Dowodzi się jedynie posiadania samoistnego przez tę osobę rzeczonej nieruchomości na początku i na końcu wspomnianego okresu. Ta norma zatem nakazuje, w terminologii przyjętej przez W. Patryasa, częściowe nieadekwatne odzwierciedlenie wyników postępowania dowodowego.

Wojciech Patryas, analizując kilka konkurencyjnych poglądów dotyczących budowy normy leżących u podstaw domniemań prawnych, uznaje, że powyższa treść normy jest adekwatna, aczkolwiek powinna być uzupełniona o kilka elementów, na przykład należałoby wprowadzić do jej treści informację o zasadzie swobodnej oceny dowodów. Warto dalej zauważyć, że norma powyższa nieuzupełniona żadna dodatkowa informacja byłaby jednak odczytywana jako zastrzegająca w swej hipotezie, że sąd rejonowy przeprowadził postępowanie dowodowe wykazujące, iż dana osoba posiadała samoistnie określoną nieruchomość przez co najmniej trzydzieści lat. Przeto zastąpienie w jakimkolwiek wytworze normatywnym jej hipotezowym uproszczeniem prowadziłoby do wytworu o odmiennej zawartości normatywnej aniżeli wytwór wyjściowy. Aby temu zapobiec, W. Patryas proponuje wprowadzić dodatkowe wyrażenie precyzujące, jaki fakt musi być wykazany w przeprowadzonym postępowaniu dowodowym. Tym wyrażeniem jest wyrażenie, które brzmi:

domniemywa się ciągłości posiadania samoistnego nieruchomości przez osobę posiadająca samoistnie tę nieruchomość w dwóch oddalonych od siebie o co najmnej trzydzieści lat momentach stanowiące domniemanie ciąłości posiadania samoistnego nieruchomości.

Jak widać, powyższe wyrażenie składa sie z dwóch części. Jego pierwszą część stanowi operator domniemaniotwórczy „domniemywa się, że”, a druga dołączone doń jako jego argument zdanie w sensie logicznym. Dlatego operator ten po dołączeniu do niego zdania w sensie logicznym daje niebędące takim zdaniem domniemanie. Zatem domniemanie to wyrażenie o szczególnej budowie (s. 86).

Jednak zdaniem wielu autorów domniemanie prawne to szczególny rodzaj normy prawnej. Zdaniem W. Patryasa wprawdzie zarówno domniemania prawne, jak i normy sa wyrażeniami, a nawet nieposiadającymi wartości logicznej zdaniami w sensie gramatycznym, ale na tym podobieństwa semiotyczne między nimi się kończą. Operator domniemaniotwórczy nie jest bowiem operatorem normatywnym, argument zaś występujący w domniemaniu stanowi fałszywe zdanie ściśle ogólne o postaci implikacji, a nie - jak się to ma w przypadku norm - zdanie konstatujące wykonanie przez określony podmiot w stosownej sytuacji wyznaczonego czynu (s. 83). 
Podobnie - argumentuje Autor - domniemania prawne nie sa definicjami. Domniemania prawne nie są zdaniami w sensie logicznym (a są nimi definicje); sa nimi argumenty do operatorów domniemaniotwórczych. Argumenty te tym również różnią się od definicji, że są fałszywe, natomiast fałszywość definicji nie budzi, czy też nie powinna budzić wątpliwości.

Dotychczasowe wywody prowadzą w prostej drodze do przyjęcia stanowiska, że usunięcie $\mathrm{z}$ wytworu normatywnego normy zakazującej częściowo nieadekwatne odzwierciedlenie wyników postępowania dowodowego zmusza do wprowadzenia w jej miejsce zestawu obejmującego hipotezowe uproszczenie tej normy oraz odpowiednie domniemanie prawne. Warto dalej zauważyć, że żaden z sądów nie składa oświadczenia wskazanego w dyspozycji powyższej normy, aby ten w postanowieniu napisał, że on w tym momencie uważa, iż osoba ta posiadała samoistnie rzeczoną nieruchomość ciagle przez co najmniej trzydzieści lat. W dyspozycji wskazuje się, by napisał, że on $\mathrm{w}$ tym momencie stwierdza nabycie przez tę osobę własności owej nieruchomości poprzez zasiedzenie.

Rodzi się zatem pytanie o podstawę przejścia od wytworu normatywnego wskazanego wcześniej do wytworu wskazanego później. Do zbadania owego ciagu niezbędnym - zdaniem W. Patryasa - elementem jest zastosowanie koncepcji performatywów (s. 120). Można zatem powiedzieć, że wyjaśnienie zaczynające się od tworu zawierającego normę nakazująca adekwatne odzwierciedlenie wyników postępowania dowodowego i normy jej towarzyszące prowadzi do wytworów, w których pojawiaja się performatywy. Przy czym pojawienie się domniemania prawnego nie zawsze towarzyszy wystąpienie performatywu. Wytwór zatem zawierający domniemania prawne nie przekształca się obligatoryjnie w wytwór wprowadzający predykat performatywny (w rodzaju ,stwierdza się, że”).

Ostatnia kwestia poruszona przez Autora jest nieco odmiennej natury. Otóż zdaniem W. Patryasa, wbrew opinii wielu innym autorów, interpretacja jakiegokolwiek aktu normatywnego nie prowadzi nigdy do odtworzenia norm, z których pewne są sformułowane w języku przedmiotowym, a pewne - w metajęzyku. Uważa, że poprawna interpretacja prawa prowadzi do odtworzenia tylko norm przedmiotowych. Jako przykład swych rozważań w tej kwestii W. Patryas analizuje dwie koncepcje norm sformułowanych przez Z. Ziembińskiego. Pierwsza z nich to koncepcja normy odtwarzanej z definicji legalnych, druga - koncepcja normy kompetencyjnej (s. 144). Zajmijmy się w tym miejscu tylko ostatnia z wyżej wymienionych.

W ujęciu Z. Ziembińskiego norma kompetencyjna jest szczególnego rodzaju normą nakazująca. Wśród nich znajduja się normy udzielające kompetencji prawodawczej oraz normy udzielające kompetencji do wykonania innych czynności niebędących stanowieniem norm. Pierwsze $\mathrm{z}$ nich to normy, które narzucaja obowiązek realizowania norm ustanowionych przez podmiot wyposażony dzięki takiej normie w kompetencję prawodawczą. Sa to zatem normy, które odnoszą się do innych norm. Byłyby zatem normami drugiego stopnia metanormami. Wojciech Patryas podaje następujący przykład. Niech będzie dany akt normatywny, który ministrowi szkolnictwa wyższego udziela 
kompetencji do określenia zachowań studentów na terenie uczelni. Następnie minister, korzystając z udzielonej kompetencji, wydaje akt normatywny składający się $\mathrm{z}$ jednego przepisu, który zawiera normę nakazującą studentom, aby siedzieli na krześle w trakcie wykładu. Zdaniem W. Patryasa z pierwszego aktu daje się odtworzyć następującą normę: „,nakazuje się studentowi, który znajduje się w sytuacji należącej do zakresu zastosowania normy: »nakazuje się każdemu studentowi wysłuchującemu wykładu, aby siedział na krześle«, aby zrealizował tę normę". Zdaniem Autora takie ujęcie norm kompetencji prawodawczej jest zbędne. Wystarczy bowiem sformułowanie pierwszej normy analizowanego przykładu. Nie widać zatem żadnej teoretycznej potrzeby operowania tego typu normami (s. 153).

II. Jak widzimy, W. Patryas odrzuca antynaturalizm jako stanowisko metodologiczne $\mathrm{w}$ prawoznawstwie, przyjmując konsekwentnie stanowisko naturalistyczne. Jednak już na wstępie należałoby zauważyć, że jest ono trudne do utrzymania, jeżeli uwzględni się to, że fakty poddane w postępowaniu dowodowym nie mają charakteru faktów jednostkowych, ale faktów społecznych, ściślej: instytucjonalnych. Podobnie ma się rzecz z występowaniem domniemań prawnych w niektórych aktach normatywnych. Wyjaśnienia powyższej konstatacji dostarcza koncepcja ontologii społecznej J. Searle'a ${ }^{4}$.

Otóż co prawda istnieje jeden świat, który jest taki, jakim mniej lub bardziej adekwatnie opisuja go nauki empiryczne, ale pod pewnymi warunkami jesteśmy $\mathrm{w}$ stanie potwierdzić istnienie $\mathrm{w}$ tym świecie szczególnego rodzaju faktów, a mianowicie: faktów instytucjonalnych. Zauważmy zatem, że nauki empiryczne sa w stanie adekwatnie opisywać i wyjaśniać zjawiska empiryczne, na przykład zmiany klimatyczne, ale nie sa w stanie uchwycić i wyjaśniać występowanie tego rodzaju obiektów, jak na przykład posiadacza własności w dobrej wierze czy też zasiedzenia. Bycie samoistnym posiadaczem w dobrej wierze, istnienie zasiedzenia nie charakteryzują się przecież właściwościami chemicznymi czy materialnymi. I nie chodzi tu o jakieś momentalne punkty w czasie pojmowanym linearnie i jego upływ na przykład od 1 lipca 1982 r. do 1 lipca $2012 \mathrm{r}$.

Nie wchodząc w szczegóły, należy podkreślić, że doniosłą cechą obiektów, takich jak posiadacz $\mathrm{w}$ dobrej wierze, jest to, że ich istnienie zależne jest od naszej wspólnej świadomości. Co więcej, istnienie świadomych stanów intencjonalnych umożliwia taką formę odnoszenia się do obiektów zewnętrznych, zdarzeń czy ludzi, które polega na nadawaniu im funkcji. Nadto, może zdarzyć się tak, że przedmioty pełnią funkcję im przypisaną nie dlatego, że posiadaja dane cechy, ale dlatego, że na podstawie kolektywnej intencjonalności doszło do uznania, iż pełnią taką właśnie funkcję. Obiekt ten pełni tę funkcję dzięki temu, że uznawany jest przez ludzi za obiekt posiadający pewien status. Samo powstawanie takich faktów oraz ich struktura przedstawiane sa $\mathrm{w}$ postaci znanej formuły, zwanej przez J. Searle’a regułą konstytutywną, a która brzmi następująco: X liczy się jako Y w kontekście C.

${ }^{4}$ Zob. szerzej: M. Smolak, Wyktadnia celowościowa z perspektywy pragmatycznej, Warszawa 2012 i cytowana tam literatura. 
Gdyby przyjąć ów ogólny opis faktów powstających na mocy określonych reguł konstytutywnych za zasadny, to powstają kolejne konsekwencje. Otóż, jeżeli na podstawie reguły tworzy się nowy rodzaj faktów (X liczy się jako posiadacz w dobrej wierze, $\mathrm{X}$ liczy się jako zasiedzenie), to ów X nabywa w ten sposób odmiennych własności. Tymi własnościami są uprawnienia i obowiązki, jakie związane sa z posiadaniem takiego statusu przez X.

Zatem nawet $\mathrm{w}$ prostej analizie przepisu o zasiedzeniu nie sposób uwolnić się od przekonania, że fakty instytucjonalne, szerzej: instytucje prawne, nie moga istnieć bez ludzkich, wzajemnych i intencjonalnych przekonań co do ich istnienia, a zatem odbiegałyby od rygorystycznie przyjmowanego kanonu naturalistycznego. Dlatego przedmiotem postępowania dowodowego nie sa fakty jednostkowe (np. ukończone trzynaście lat, choroba psychiczna, upływ czasu), ale fakty instytucjonalne, bowiem nawet fakt ukończenia trzynastu lat, a nie na przykład 300 lat w jakimś kalendarzu marsjańskim, jest faktem społecznym, nie wspominając o konsekwencjach prawnych, politycznych czy społecznych ukończenia na przykład 18 roku życia.

Podobnie rzecz się ma $\mathrm{z}$ wyjaśnianiem występowania domniemań prawnych wśród przepisów prawnych, a które przypomnijmy, polegałoby na konstruowaniu tworów normatywnych zawierających normy nakazujące częściowo nieadekwatne odzwierciedlenie wyników postępowania dowodowego i przekształceniu ich w wytwory obejmujące zestawy wyrażeń składających się na domniemania prawne. Występowanie to jest relewantne w stosunku do wzajemnych społecznych, intencjonalnych oczekiwań co do faktów, którym na mocy reguł konstytutywnych przypisuje się określone funkcje bycia domniemaniem prawnym. Tym samym wyjaśnianie występowania domniemań prawnych byłoby wyjaśnianiem faktów społecznych, a nie faktów surowych.

Nieco innego rodzaju watpliwości dostarcza koncepcja domniemania prawnego pojmowanego jako niemające wartości logicznej zdanie w sensie gramatycznym. Składa się z operatora domniemaniotwórczego oraz ściśle ogólnego, lecz ewidentnie fałszywego zdania w sensie logicznym. Powstaje pytanie, jak to jest możliwe, że akceptujemy zdanie odnoszące się do rzeczywistości (np. posiadania danej rzeczy przez trzydzieści lat), a które jest ewidentnie (potencjalnie) fałszywe. Czy tylko dlatego, że jest poprawnie uzasadnione, a jeszcze nieuznawane? Wojciech Patryas uznaje, że zdanie jest uznawane za prawdziwe od momentu, gdy staje się sądem, a zatem uzasadnia się zdanie wcześniej przez kogoś uznawane.

Można jednak zaproponować nieco inne podejście. Otóż należy podkreślić, że dokonywanie aktów mowy, w tym aktu ,domniemywa się, że”, podlega pewnym pragmatycznym regułom komunikacji językowej. Naruszenie tych reguł sprawia, że dany akt lokucyjny nie jest skutecznie dokonany. Następnie należy odróżnić ustalenie co do faktów od samego aktu dokonania takiego ustalenia. Akt dokonania ustalenia faktu jest czynnością (aktem mowy), a zdanie formułujące to ustalenie jest wytworem tej czynności. Jako akt mowy ustalenie faktu ma charakter stwierdzenia. Jego osobliwość polega na tym, że w odróżnieniu od aktów mowy sformułowanych w języku naturalnym, jego ocena 
niewadliwości (prawidłowości) podlega nie tylko regułom pragmatycznym języka naturalnego, lecz także odpowiednim przepisom prawnym. Należy nadto podkreślić, że wymiar wadliwości/niewadliwości odnosi się do ustalania faktów, a nie do wytworów owej czynności ustalania faktów. Warto zatem pamiętać, że przepisy prawne rządzą czynnościami, a nie wytworami. Reguła może zostać naruszona tylko przez czynność, która tej regule podlega.

Dlatego właśnie prawnicy używają określenia fakty udowodnione w odniesieniu do zdań będących wytworami ustaleń pojmowanych jako czynności, a co do których można zasadnie przyjąc, że sa to zdania fałszywe. Za prawdziwe (ewentualnie prawidłowo uzasadnione) prawnicy skłonni sa uznawać takie zdania, które są wytworami niewadliwych ustaleń co do faktów, natomiast za nieprawdziwe czy też nieuzasadnione takie zdania, które są wytworami wadliwych ustaleń co do faktów. Dlatego tam gdzie przywołuje się fakty, chodzi nie o kognitywne określenie operacji, lecz o decyzje podjęte na podstawie określonych reguł. Reguły te moga być różnorodne i $\mathrm{w}$ rozmaity sposób racjonalizować działalność sądów. Na przykład racjonalizacja polega na dążeniu do ułatwienia sądowi dokonania ustaleń co do faktów, których wytworami będą zdania co do występowania określonych faktów ${ }^{5}$.

Inna wątpliwość wiąże się z performatywnym charakterem zwrotu „domniemywa się, że”. Gdyby uznać, że zwrot: „domniemywa się, że” jest aktem illokucyjnym, to powstaje pytanie, czy istnienie jakiś konwencjonalny związek na przykład między aktem illokucyjnym: domniemywa się, że X jest posiadaczem w dobrej wierze, a perlokucyjnym aktem przekonania, że X istnieje i jest posiadaczem w dobrej wierze ${ }^{6}$.

Innymi słowy, jeżeli jakaś osoba wypowiada akt mowy: ,domniemywa się, że $\mathrm{X}$, ponieważ Y”, to zawsze wyraża intencje do przekonania jakiegoś L do zaakceptowania, że istnieje jakiś $\mathrm{X}$ ze względu na Y. Należy przy tym zauważyć, że związek pomiędzy aktem illokucyjnym a związanym $z$ nim aktem perlokucyjnym jest określony jako związek konieczny i - zgodnie z teorią aktów mowy J. Searle’a - koresponduje z jakąś reguła konstytutywną. Ściśle powiązana illukucyjnie perlokucja nadaje sens aktowi illokucyjnemu. Powstaje pytanie nie tyle o konwencjonalność tego związku, ile raczej o to, czy perlokucja aktu illokucyjnego, jakim jest akt: ,,domniemywa się, że”, jest tutaj przekonanie kogoś co do zajścia określonego faktu.

III. To co wyróżnia omawianą książkę, to fakt, że jest pierwszą pozycją, która $\mathrm{w}$ badaniach nad domniemaniami prawnymi idzie odmienna droga aniżeli dotychczasowe publikacje. Autor przekonująco argumentuje na rzecz ujmowania domniemania jako zdania niemającego wartości logicznej, o którego wzruszalności nie decyduje jego zawartość, lecz postać normy, której usunięcie to domniemanie wprowadza. Koncepcja wyjaśniania strukturalnego występowania

\footnotetext{
${ }^{5}$ Por. T. Gizbert-Studnicki, Prawda sqdowa w postepowaniu cywilnym, „Państwo i Prawo” 2009, z. 7 .

${ }^{6}$ Por. P. J. van den Hoven, Legal Argumentation as an Illocutionary Act Complex: A Critical Analisis, „International Journal for the Semiotics of Law” 1, 1988, nr 1.
} 
w normach prawnych domniemań prawnych W. Patryasa oferuje nowa aparaturę pojęciową pozwalająca nazwać to, co prawnicy intuicyjnie wyczuwaja, a mianowicie, że domniemania prawne stanowią swoistego rodzaju zdania składające się z operatora domniemaniotwórczego ,domniemywa się, że” oraz zdania w sensie logicznym. Wreszcie wprowadza nowe wątki do dyskusji teoretycznoprawnej dotyczącej statusu norm kompetencyjnych. Bez wątpienia stanowi źródło inspiracji do dalszych badań nad systemem prawnym opartym na paradygmacie naturalistycznym, natomiast antynaturalistów intelektualnie prowokuje do kontrataku, a co najmniej do obrony ich stanowiska.

dr hab. Marek Smolak

Profesor Uniwersytetu im. Adama Mickiewicza w Poznaniu

$i$ Uniwersytetu Kardynata Stefana Wyszyńskiego $w$ Warszawie 